Original Research Article

\title{
Price variation in different brands of anticancer drugs available in Indian pharmaceutical market: a cost analysis study
}

\author{
Sandeep Kumar Adwal, Ruchi Baghel*
}

Department of Pharmacology, R. D. Gardi Medical College, Ujjain, Madhya Pradesh, India

\begin{abstract}
Background: Cancer is one of the most expensive and lethal noncommunicable diseases globally. Availability and affordability of anticancer drugs are the most important factors on which management of cancer depends. The objective of the study was to evaluate the variation of cost among different brands of anti-cancer drugs available in the Indian market.
\end{abstract}

Received: 05 February 2019

Revised: 02 March 2019

Accepted: 06 March 2019

*Correspondence to:

Dr. Ruchi Baghel,

Email: drruchisingh08@

gmail.com

Copyright: (C) the author(s), publisher and licensee Medip Academy. This is an openaccess article distributed under the terms of the Creative Commons Attribution NonCommercial License, which permits unrestricted noncommercial use, distribution, and reproduction in any medium, provided the original work is properly cited.

Methods: "Current Index of Medical Specialties" July-October 2018 and "Drug Update" Sept - 2018 were used to obtain cost in INR* (Indian National Rupees) of anticancer drugs manufactured by different pharmaceutical companies in India, in the same strength and dosage form. Percentage cost variations were calculated by minimum and maximum costs of anticancer drug of different brands.

Results: Percentage variation in cost was analyzed for 41 different formulations of 27 anticancer drugs. Highest cost variability seen with Alkylating agent Carboplatin $150 \mathrm{mg}$ injection (1100\%) and lowest with Antimetabolite anticancer agent Cytarabine $500 \mathrm{mg}$ injection (6.56\%). Three formulations showed more than $500 \%$ cost variation, largest with Carboplatin $150 \mathrm{mg}$ injection $(1100 \%)$ followed by Anastrozole $1 \mathrm{mg}$ tablet $(870 \%)$ and Letrozole $1 \mathrm{mg}$ tablet $(508.42 \%)$.

Conclusions: Present study finding showed significant cost variation in different brand of many anticancer drugs in India. These results indicated that greater price transparencies required. This price variation issue requires a much more in-depth analysis of the health care system.

Keywords: Anticancer, Cancer, Cost analysis, Cost variation, Pharmacoeconomic

\section{INTRODUCTION}

Cancer is a large group of disease characterized by abnormal pattern of growth and differentiation of body cells which can affect almost any part of the body. It is one of the most expensive and lethal noncommunicable diseases globally. ${ }^{1}$ In 2018 around 2.25 million people living with the cancer and total deaths due to cancer was around 7,84,821 in India. ${ }^{2}$

Chemotherapy with anticancer drugs is the main treatment modality for many cancers. Early diagnosis and longer duration of treatment with chemotherapeutic agents contribute to high cost of medicine for cancer care. Availability and affordability of anticancer drugs are the most important factors on which management of cancer depends. Global spending on cancer medicines expanded from $\$ 96$ billion in 2013 to $\$ 133$ billion globally in $2017 .^{3}$ Cost of drug is a very sensitive issue for a developing country like India. It has direct economic implications on patients and plays a significant role for compliance to treatment. The affordability of anticancer medicines is a critical problem for most of the Indian patients.

In developing countries like India pharmacoeconomics plays an important role in healthcare sector. 
Cost of drugs also plays an important role in adherence of treatment of disease and also is an essential part of rational drug prescribing. Indian pharmaceutical market flooded with a number of branded formulations for anticancer drugs with large cost variation of the same drug. This cost variation employs an unnecessary economic burden on the patients. ${ }^{4}$

One of the types of partial pharmacoeconomic evaluation is 'Cost analysis' by which we can compare the costs of two or more alternatives without regard to outcome. ${ }^{5,6}$ As alternatives different brand formulations of the same drug also available for a patient, expected to provide a same therapeutic outcome. Analysis of the costs of various brand of same drug can highlight the phenomenon of 'inter-brand price variation' which can put the substantial financial burden on patients.

Various researches indicated significantly higher cost variations in different brands of single drug and changing trend of cost variation in different time periods. There are very few studies available that compared the cost of the anticancer drug of different brands available in India. Present study aimed to review the costs and percentage cost variation of anticancer agents across the different brands available in the Indian market.

\section{METHODS}

This cost analysis study was done in the Department of Pharmacology of a Tertiary Care Teaching Hospital in Central India. Price in INR* (Indian National Rupees) of anticancer drugs manufactured by different pharmaceutical companies in India, in the same strength and dosage form was obtained from "Current Index of Medical Specialties" July-October 2018 and "Drug Update" Sept - 2018.

Costs of drug were analyzed according to the availability like oral and parenteral dosage form. The drugs were further divided into groups like antimetabolite and alkylating agent. Different strengths of the same drug manufactured by only one company or by different companies were excluded. Formulations containing combination of drugs were also excluded.

Costs of individual drug with same being manufactured by all the companies in the same strength and dosage form were compared. Cost of the oral anticancer drug formulation was calculated for single tablet as the number of tablets available per strip varied.

The difference in the maximum and minimum price of Individual drug being manufactured by several companies across the different brands was calculated. This formula was used to calculate the variation in price. $^{7}$

$\%$ Cost variation $=$ Cost of brand with highest price-cost of brand with lowest price $\mathrm{x} 100 /$ cost of brand with lowest price.

\section{RESULTS}

Percentage price variations of 27 drugs costs in different dosages form were calculated. A total of 41 different formulations were available for these drugs, which were manufactured by various pharmaceutical companies in India. According to various classes of anti-cancer drugs analyzed in this study, the maximum mean price variability was found to be highest with hormonal drugs (326.62\%) and lowest with microtubules damaging anti-cancer drugs $(86.33 \%)$ (Figure 1).

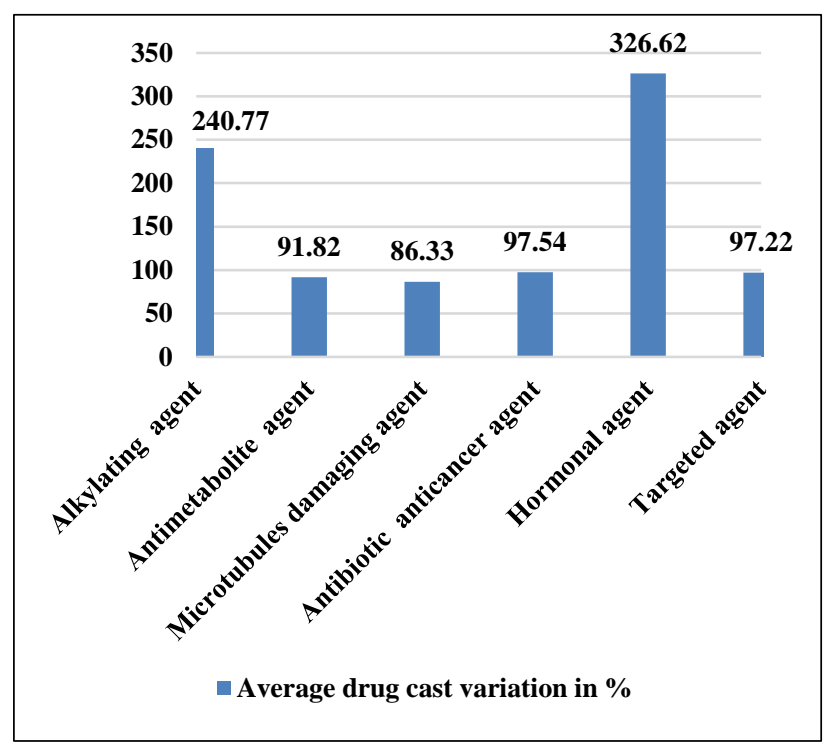

\section{Figure 1: Cost variation (percentage) among various categories of anti-cancer drugs.}

Out of the 41 formulations 17 formulations show more than $100 \%$ variation in the maximum and minimum cost. Three formulations showed more than $500 \%$ variation, largest with Carboplatin $150 \mathrm{mg}$ injection $(1100 \%)$ followed by Anastrozole $1 \mathrm{mg}$ tablet (870\%) and Letrozole $1 \mathrm{mg}$ tablet $(508.42 \%)$.

Table 1 shows cost variation in Alkylating agents with highest variability with Carboplatin $150 \mathrm{mg}$ injection $(1100 \%)$ and lowest with Ifosfamide $1000 \mathrm{mg}$ injection $(48.04 \%)$ (Table 1).

In Antimetabolite anticancer agents, highest cost variability seen with Methotrexate $2.5 \mathrm{mg}$ tablet $(253.02 \%)$ and lowest with Cytarabine $500 \mathrm{mg}$ injection (6.56\%) (Table 2).

Among the microtubules damaging anticancer agent highest cost variation show by Paclitaxel $100 \mathrm{mg}$ injections (165.89\%) and in antibiotic anticancer agent Mitomycin 2 mg injection show maximum cost difference $(222.28 \%)$ (Table 3 and Table 4). In hormonal anticancer agent, 2 drugs showed cost variation more than $500 \%$, Anastrozole $1 \mathrm{mg}$ tablet (870\%) and Letrozole $1 \mathrm{mg}$ tablet (508.42\%). Minimum cost variation in this group seen with Flutamide $250 \mathrm{mg}$ tablet $(69.12 \%)$ (Table 5). 
Table 1: Cost variation among alkylating anticancer agent.

\begin{tabular}{|c|c|c|c|c|c|c|}
\hline Drug & Dosage form & Dose (mg) & $\begin{array}{l}\text { No. of manufacturing } \\
\text { companies }\end{array}$ & $\begin{array}{l}\text { Minimum cost } \\
\text { (INR)* }\end{array}$ & $\begin{array}{l}\text { Maximum } \\
\text { cost (INR)* }\end{array}$ & $\begin{array}{l}\% \text { variation } \\
\text { in cost }\end{array}$ \\
\hline \multirow{2}{*}{ Cyclophosphamide } & \multirow{2}{*}{ Injection } & 200 & 10 & 26.00 & 46.15 & 77.5 \\
\hline & & 500 & 9 & 58.00 & 98.30 & 69.48 \\
\hline Ifosfamide & Injection & 1000 & 10 & 322.21 & 477.00 & 48.04 \\
\hline Buslfan & Tablet & 2 & 7 & 2.60 & 6.84 & 163.07 \\
\hline Cisplatin & Injection & 1 & 16 & 7.70 & 20.70 & 168.83 \\
\hline \multirow{2}{*}{ Oxaliplatin } & Injection & 50 & 13 & 1850.00 & 4798.00 & 159.35 \\
\hline & Injection & 100 & 11 & 4000.00 & 9594.50 & 139.86 \\
\hline Carboplatin & Injection & 150 & 15 & 150.00 & 1800.00 & 1100 \\
\hline
\end{tabular}

Table 2: Cost variation among antimetabolite anticancer agent.

\begin{tabular}{|c|c|c|c|c|c|c|}
\hline Drug & Dosage form & Dose (mg) & $\begin{array}{l}\text { No. of manufacturing } \\
\text { companies }\end{array}$ & $\begin{array}{l}\text { Minimum } \\
\text { cost (INR)* }\end{array}$ & $\begin{array}{l}\text { Maximum cos } 1 \\
\text { (INR)* }\end{array}$ & $\begin{array}{l}\% \text { variation } \\
\text { in cost }\end{array}$ \\
\hline \multirow{3}{*}{ Methotrexate } & Tablet & 2.5 & 15 & 1.49 & 5.26 & 253.02 \\
\hline & Injection & 15 & 9 & 25.50 & 59.25 & 132.35 \\
\hline & Injection & 50 & 10 & 49.90 & 105.00 & 110.42 \\
\hline Fluorouracil & Injection & 250 & 8 & 10.30 & 14 & 35.92 \\
\hline \multirow{2}{*}{ Cytarabine } & Injection & 100 & 6 & 125.00 & 185.00 & 48 \\
\hline & Injection & 500 & 5 & 549.00 & 585.00 & 6.56 \\
\hline \multirow{2}{*}{ Gemcitabine } & Injection & 200 & 11 & 1070.00 & 1625.00 & 51.87 \\
\hline & Injection & 1000 & 10 & 4220.00 & 8290.00 & 96.45 \\
\hline
\end{tabular}

Table 3: Cost variation among microtubules damaging anticancer agent.

\begin{tabular}{|lllllll|}
\hline Drug & Dosage form & Dose $(\mathbf{m g})$ & $\begin{array}{l}\text { No. of manufacturing } \\
\text { companies }\end{array}$ & $\begin{array}{l}\text { Minimum } \\
\text { cost (INR)** }\end{array}$ & $\begin{array}{l}\text { Maximum } \\
\text { cost (INR)* }\end{array}$ & $\begin{array}{l}\text { \% variation } \\
\text { in cost }\end{array}$ \\
\hline \multirow{2}{*}{ Paclitaxel } & Injection & 30 & 15 & 1087.00 & 2100.00 & 93.19 \\
& Injection & 100 & 15 & 3720.00 & 9891.00 & 165.89 \\
\hline \multirow{2}{*}{ Docetaxel } & Injection & 20 & 12 & 3190.00 & 4633.00 & 45.24 \\
& Injection & 80 & 11 & 5400.00 & 12280.00 & 127.41 \\
\hline Vincristine & Injection & 1 & 8 & 48.00 & 63.25 & 31.77 \\
\hline Vinorelbine & Injection & 10 & 6 & 2501.00 & 3864.00 & 54.50 \\
\hline
\end{tabular}

Table 4: Cost variation among antibiotic anticancer agent.

\begin{tabular}{|lllllll|}
\hline Drug & Dosage form & Dose $(\mathbf{m g})$ & $\begin{array}{l}\text { No. of manufacturing } \\
\text { companies }\end{array}$ & $\begin{array}{l}\text { Minimum } \\
\text { cost (INR)* }\end{array}$ & $\begin{array}{l}\text { Maximum } \\
\text { cost (INR)* }\end{array}$ & $\begin{array}{l}\text { \% variation } \\
\text { in cost }\end{array}$ \\
\hline \multirow{2}{*}{ Doxorubicin } & Injection & 10 & 16 & 192.50 & 351.00 & 82.34 \\
& Injection & 50 & 13 & 921 & 1540.00 & 67.21 \\
\hline Daunorubicin & Injection & 20 & 5 & 240.00 & 431.00 & 79.58 \\
\hline \multirow{2}{*}{ Epirubicin } & Injection & 10 & 9 & 387.45 & 650.00 & 67.76 \\
& Injection & 50 & 9 & 1788.00 & 2977.00 & 66.50 \\
\hline \multirow{2}{*}{ Mitomycin } & Injection & 2 & 7 & 65.16 & 210.00 & 222.28 \\
& Injection & 10 & 6 & 326.20 & 643.00 & 97.12 \\
\hline
\end{tabular}

Table 6 shows cost variation in targeted anticancer agents with highest variability with Erlotinib $150 \mathrm{mg}$ tablet $(230.33 \%)$ and lowest with Imatinib $100 \mathrm{mg}$ capsule (17.65\%) (Table 6).

\section{DISCUSSION}

The main objective of this study was analysing the variation of cost among different brands of anti-cancer drugs available in the Indian market. Study showed a very high fluctuation in the minimum and maximum price of most of the anticancer agents which is being manufactured by several companies across the different brands in India. In this study, alkylating anticancer agent Carboplatin showed the highest price variation $(1100 \%)$ followed by Anastrozole (870\%), Letrozole (508.42). Methotrexate (253.02\%), Mitomycin (222.08\%) and Erlotinib $(230.33 \%)$. Lowest price variation found with Cytarabine 
(06.56\%), Bortezomib (31.26\%), Gefitinib (38.80\%) and Rituximab (40.08\%). Study done by Kosalani BP et al, also showed a very high fluctuation in cost of anticancer drugs in Indian market. Their study showed highest cost variation in hormonal anticancer drugs $(714.24 \%)$ and lowest variation with targeted anticancer drugs $(5.56 \%)$ in India. ${ }^{8}$ A study by Salmasi $\mathrm{S}$ et al, also concluded great variation in pricing of anticancer drugs in other countries like in South East Asian, Western Pacific and East Mediterranean Region. ${ }^{9}$

Table 5: Cost variation among hormonal anticancer agent.

\begin{tabular}{|lllllll|}
\hline Drug & Dosage form & Dose (mg) & $\begin{array}{l}\text { No. of manufacturing } \\
\text { companies }\end{array}$ & $\begin{array}{l}\text { Minimum } \\
\text { cost (INR)* }\end{array}$ & $\begin{array}{l}\text { Maximum } \\
\text { cost (INR)* }\end{array}$ & $\begin{array}{l}\text { \% variation } \\
\text { in cost }\end{array}$ \\
\hline \multirow{2}{*}{ Tamoxifen } & Tablet & 10 & 14 & 1.60 & 3.33 & 108.13 \\
& Tablet & 20 & 7 & 3.10 & 5.50 & 77.42 \\
\hline Anastrozole & Tablet & 1 & 7 & 6.00 & 58.20 & 870 \\
\hline Letrozole & Tablet & 2.5 & 15 & 9.50 & 57.80 & 508.42 \\
\hline Flutamide & Tablet & 250 & 4 & 6.80 & 11.50 & 69.12 \\
\hline
\end{tabular}

Table 6: Cost variation among targeted anticancer agent.

\begin{tabular}{|c|c|c|c|c|c|c|}
\hline Drug & Dosage form & Dose (mg) & $\begin{array}{l}\text { No. of manufacturing } \\
\text { companies }\end{array}$ & $\begin{array}{l}\text { Minimum } \\
\text { cost (INR)* }\end{array}$ & $\begin{array}{l}\text { Maximum } \\
\text { cost (INR)* }\end{array}$ & $\begin{array}{l}\% \text { variation } \\
\text { in cost }\end{array}$ \\
\hline \multirow{2}{*}{ Imatinib } & Capsule & 100 & 5 & 85.00 & 100.00 & 17.65 \\
\hline & Tablet & 400 & 7 & 180.00 & 413.33 & 129.63 \\
\hline Gefitinib & Tablet & 250 & 7 & 285.60 & 396.4 & 38.80 \\
\hline Erlotinib & Tablet & $\begin{array}{l}150 \\
100\end{array}$ & $\begin{array}{l}4 \\
2\end{array}$ & $\begin{array}{l}333.00 \\
222.00\end{array}$ & $\begin{array}{l}1100.00 \\
650.00\end{array}$ & $\begin{array}{l}230.33 \\
192.79\end{array}$ \\
\hline Bortezomib & Injection & 2 & 5 & 11982.00 & 15727.40 & 31.26 \\
\hline Rituximab & Injection & 100 & 4 & 7138.00 & 9999.00 & 40.08 \\
\hline
\end{tabular}

There are only few Studies in India comparing the cost of the same drug sold under different brand names by different pharmaceutical companies especially in case of anticancer drug. Various brands of the same drug show difference in their cost varies from two-fold to more than 100 -fold. ${ }^{10}$ The nature and composition of pharma sector in India which is predominantly a branded generic market is the one of the important reasons for brand cost variation in Indian pharmaceutical market.

The number of brands available in the Indian market is very high around $60,000-70,000 .{ }^{11}$ Some other factors like the asymmetry of information or imperfect information, government regulations and pricing policies, costs of raw supplies, distribution and promotion, economic goals of the parent company, target return on investment also contribute to this phenomenon as evident from the literature. ${ }^{12-15}$

In India, the Drug Price Control Order (DPCO) controls the price of drugs. National Pharmaceutical Pricing Authority (NPPA) regulates the price of drugs in India with limited authority to fix, review and justify pharmaceutical prices under the Drug Prices Control Order (DPCO), 1995. The market-based pricing (MBP) mechanism used by DPCO to set the price of the drug is highly debatable and has come under severe criticism from various Non-governmental organizations (NGOs). ${ }^{16}$

In developed countries, system of medical insurance is in place but in developing countries like India a large number of patients are not covered under any individual or government medical insurance so most of the cancer patients have to purchase the prescribed drugs by themselves. The large differences in the cost of different formulations of the same anticancer drug have severe economic implications on the Indian Population. Many cancer patients are most likely to abandon use of their medications or cut their doses because the treatment is not affordable for them. This may cause a higher risk of disease progression, mortalities and morbidities. The treating Physicians prescribe only that brand about which they know. They have lack of information about other brands with lower price and this existence of wide variation in prices. Various studies showed that if a provisional manual of drug prices is available to the physicians, it will reduce the cost of therapy and also help health care providers for allocating their limited health care resources. ${ }^{17,18}$ Governing authorities should take some steps for regulating and bring uniformity in price. So that a common man enables affordable access to potentially life-saving drugs which will ultimately improve the compliance and reduce the economic burden. 


\section{CONCLUSION}

The significant price differences among various anticancer drugs very evident. Present study finding also showed significant cost variation in different brand of many anticancer drugs in India. These results indicated that greater price transparencies required. This price variation issue requires a much more in-depth analysis of the health care system. Results of this type of price variation studies provide information to the prescriber about various brands with their price variations and help them to choose to cost effective drugs for a patient to achieve rational prescribing. It also helps policy makers to compare the price of drugs of different brands in the country and to decide if further policy measures related to drug prices are required.

Funding: No funding sources Conflict of interest: None declared

Ethical approval: Not Required

\section{REFERENCES}

1. Albreht T, McKee M, Alexe DM, Coleman MP, Martin-Moreno JM. Making progress against cancer in Europe in 2008. Euro J Cancer. 2008;44(10):1451-6.

2. NICPR. Cancer Statistics. India against cancer. Available at: http://cancerindia.org.in/cancerstatistics/.

3. IQVIA. Global Oncology Trends, 2018. Available at: https://www.iqvia.com/institute/reports/globaloncology-trends-2018.

4. Das SC. A critical study on availability and price variation between different brands: impact on access to medicines. Ind $\mathrm{J}$ Pharmaceutical Sci. 2007;69(1):160.

5. Ahuja J, Gupta M, Gupta AK, Kohli K. Pharmacoeconomics. National Med J Ind. 2004; 17(2):80-3.

6. Trask L. Pharmacoeconomics: Principles, methods, and applications. In: DiPiro JT, Talbert RL, Yee GC, Matzke GR, Wells BG, Posey L, eds. Pharmacotherapy: a pathophysiologic approach. 8th ed. New York, NY: McGraw-Hill; 2011.

7. Trask L. Pharmacoeconomics: Principles, methods, and applications. In: DiPiro JT, Talbert RL, Yee GC, Matzke GR, Wells BG, Posey L, eds. Pharmacotherapy: a pathophysiologic approach. 8th ed. New York, NY: McGraw-Hill; 2011.
8. Kolasani BP, Malathi DC, Ponnaluri RR. Variation of cost among anti-cancer drugs available in Indian market. JCDR. 2016;10(11):FC17.

9. Salmasi S, Lee KS, Ming LC, Neoh CF, Elrggal ME, Khan TM, et al. Pricing appraisal of anti-cancer drugs in the South East Asian, Western Pacific and East Mediterranean Region. BMC Cancer. 2017;17(1):903.

10. Lofolm PW, Katzug BG. Rational prescribing and prescription writing. In: Katzug BG, eds. Basic and Clinical Pharmacology, 9th ed. New York: McGrawHill; 1091-100.

11. Thomas M. Rational drug use and essential drug concept. In: Parthasarthi G, Nyfort-Hasen K. eds. A textbook of clinical pharmacy practice. 1st ed. Himayatnagar, Hyderabad: Orient Longman; 2004: 72-3.

12. Sarkar PK. A rational drug policy. Ind J Med Ethics. 2004;1(1):11-2.

13. Roy V, Rewari S. Ambiguous drug pricing: a physician's dilemma. Ind J Pharmacol. 1998;30(6):404.

14. Wertheimer AI, Grumer SK. Overview of international pharmacy pricing. Pharmacoeconomics. 1992;2(6):449-55.

15. Berki SE, Richards JW, Weeks HA. The mysteries of prescription pricing in retail pharmacies. Med Care. 1977; 15(3):241-50.

16. NPPA. Compendium of notified ceiling prices of scheduled drugs. National Pharmaceutical Pricing Authority, 2015. Available at: http://www.nppaindia.nic.in/englishcompendium201 5.pdf.

17. Frazier LM, Brown JT, Divine GW, Fleming GR, Philips NM, Siegal WC, et al. Can physician education lower the cost of prescription drugs?: a prospective, controlled trial. Ann Inte Med. 1991;115(2):116-21.

18. Badia X, Russo P, Attanasio E. A comparative economic analysis of simvastatin versus atorvastatin: results of the surrogate marker cost-efficacy (SMaC) study. Clin Therapeutics. 1999;21(10):1788-96.

Cite this article as: Adwal SK, Baghel R. Price variation in different brands of anticancer drugs available in Indian pharmaceutical market: a cost analysis study. Int $\mathrm{J}$ Basic Clin Pharmacol 2019;8:642-6. 